\title{
Sprawozdanie z Międzynarodowej Konferencji Naukowej „Młodzież czasów przemian społeczno-kulturowych. Od kontekstów teoretyczno-empirycznych do praktyki socjalno-wychowawczej w perspektywie międzynarodowej"
}

\section{Poznań, 14 listopada 2014 roku}

Z inicjatywy Zakładu Pedagogiki Społecznej, 14 listopada 2014 roku na Wydziale Studiów Edukacyjnych Uniwersytetu im. Adama Mickiewicza w Poznaniu odbyła się Międzynarodowa Konferencja Naukowa na temat: „Młodzież czasów przemian społeczno-kulturowych. Od kontekstów teoretyczno-empirycznych do praktyki socjalno-wychowawczej w perspektywie międzynarodowej". Jej celem było ukazanie szerokiego spektrum zagadnień dotyczących współczesnej młodzieży. Koncentrowały się one wokół następującej problematyki:

- Edukacyjne wybory młodzieży i ich konsekwencje;

- Młodzież a kultura współczesna;

- Przemiany podstawowych środowisk wychowawczych i ich konsekwencje socjalizacyjno-wychowawcze (np. rodzina, szkoła, grupa rówieśnicza, Kościół, mass media);

- Poszukiwanie dobrych praktyk socjalno-wychowawczych. Od tradycji ku nowoczesnym rozwiązaniom.

Konferencja składała się z czterech sesji plenarnych, a każda została opatrzona tytułem i myślą przewodnią. Wskazywały one na zakres podejmowanej problematyki w danej części oraz na jej złożoność i bogactwo.

Doktor hab. Katarzyna Segiet - Przewodnicząca Komitetu Naukowego - powitała przybyłych gości: przedstawicieli Technische Universität Cottbus - Senftenberg, pracowników naukowych Wydziału, studentów i przedstawicieli praktyki społecznej. Następnie Dziekan Wydziału Studiów Edukacyjnych Uniwersytetu im Adama Mickiewicza prof. zw. dr hab. Zbyszko Melosik wygłosił krótkie przemówienie otwierające obrady naukowe. Z kolei, dr hab. Katarzyna Segiet wprowadziła wszystkich słuchaczy w problematykę konferencji. W swojej wypowiedzi zwróciła szczególną uwagę, że młodzież oraz kwestia młodości to aktualnie doniosłe zjawisko społeczne, które obecnie stanowi przedmiot żywego zainteresowania wielu badaczy. W dalszej części wypowiedzi zwróciła uwagę, że rozwój wiedzy, wielość nurtów oraz poglądów, niekiedy bardzo zróżnicowanych, na temat młodzieży uzasadnia potrzebę zorganizowanej konferencji, która tworzy tym sposobem przestrzeń do dyskusji na temat powyższych zagadnień. Następnie dr hab. Katarzyna Segiet oddała głos moderatorom konferencji: dr hab. Waldemarowi Segietowi i dr Kamili Słupskiej.

Doktor hab. Waldemar Segiet wprowadził słuchaczy w problematykę pierwszej sesji plenarnej konferencji, zatytułowanej: Konstruowanie tożsamości wspótczesnej młodzieży, której hasłem przewodnim były słowa: Młodzież poszukuje sposobów ekspresji 
własnej tożsamości, dostrzega wielorakość możliwości. Moderator ten zwrócił uwagę, że namysł nad młodzieżą z racji charakterystycznej dla niej dużej dynamiki rozwoju oraz specyficznej adekwatności do przemian cywilizacyjno-kulturowych zachodzących w otaczającej nas rzeczywistości wiąże się z próbą znalezienia odpowiedzi na wiele pytań. Najistotniejsze w tym kontekście jest pytanie o tożsamość współczesnej młodzieży, które wydaje się być współczesną wersją pytania o kondycję młodego człowieka. Pierwszym prelegentem sesji, był prof. zw. dr hab. Zbyszko Melosik. W swoim referacie zatytułowanym: Pedagogika i tożsamość młodzieży w kulturze kontroli i rozproszenia przedstawił opis rzeczywistości popkulturowej, ukazując wybrane jej codzienne fenomeny i zjawiska w kontekście tożsamości młodzieży. Następnie, prof. dr. phil. Urlich Paetzolt wygłosił wykład na temat: Jugend als Problem (Młodzież jako problem), w którym postawił dwie istotne tezy odnoszące się do pedagogiki społecznej. Pierwsza wskazuje, iż pedagogika społeczna i praca socjalna w swych działaniach profilaktycznych i kompensacyjnych skupiają się przede wszystkim na adolescentach. Zbyt mocno koncentrują one swoje działania na fazie młodzieńczej, nie doceniając tym samym istoty wcześniejszych faz rozwojowych. Druga teza podkreślała, że im bardziej pedagogika społeczna ingeruje w życie młodych ludzi, tym bardziej ogranicza im możliwość rozwijania samodzielności. Ostatnim wykładem w tej części konferencji było wystąpienie prof. dr hab. Barbary Smolińskiej-Theiss: Dzieci z dobrych rodzin - nieprzerwana pepowina. Zaprezentowano $\mathrm{w}$ nim istotę oraz specyfikę relacji dzieci z tzw. dobrych domów z ich rodzicami oraz kontekst wychowawczo-edukacyjny, w którym funkcjonują. Doktor hab. Waldemar Segiet podsumował pierwszą część plenarną konferencji. Wiek dorastania jest okresem wyborów, dezintegracji i integracji tożsamości w sferze wartości, stylu życia, krystalizacji dążeń i w tym kontekście młodzież wydaje się być tą grupą, która przede wszystkim podlega socjalizacyjnym eksperymentom historii i stanowi społeczne laboratorium doświadczalne.

W dalszej części dr Kamila Słupska wprowadziła wszystkich uczestników w tematykę drugiej sesji plenarnej, noszącej tytuł: Między edukacja a rynkiem pracy. Hasłem przewodnim były słowa: „Młodzież określa własne wybory, dążenia, własne drogi, a w konsekwencji perspektywę życia". Pani Doktor zwróciła uwagę, że myślenie o przyszłości zmienia się w okresie adolescencji w wyniku procesów psychicznych, biologicznych, w powiązaniu z przekształcaniem kontekstu życiowego. Obiektywne czynniki wyznaczają subiektywne podejście do takich perspektyw, jak np. możliwości edukacyjne, możliwości zawodowe, plany dotyczące życia rodzinnego. Kariera zawodowa, będąca niezwykle ważnym elementem składowym szeroko pojmowanej kariery życiowej i następstwem wędrówki edukacyjnej, nie jest obietnicą realnego powodzenia, które pozostaje w sferze marzeń, ale budzi obawy o własne umiejętności i możliwości odniesienia sukcesu. Pierwsze wystąpienie w drugiej sesji plenarnej wygłosiła prof. dr hab. Agnieszka Gromkowska-Melosik. Tematem referatu była: Dynamika dostęu młodych kobiet $i$ mężczyzn do szkolnictwa wyższego. Studium z pedagogiki porównawczej. Kluczową konkluzją wystąpienia Pani Profesor było wskazanie, iż procent studiujących kobiet wzrasta, jednak nie przekła- 
da się to na wzrost liczby kobiet studiujących w placówkach o tym samym prestiżu, w których studiują mężczyźni. Następnie ze swoim referentem, zatytułowanym: Młodzież a kariera traktowana jako własność jednostki, wystąpiła prof. dr hab. Agnieszka Cybal-Michalska. W tym wystąpieniu swym Pani Profesor podjęła próbę udzielenia odpowiedzi na pytania: jak współcześnie młodzież pozycjonuje karierę oraz z czym młodzi ludzie karierę utożsamiają? Kolejną prelegentką była prof. dr hab. Magdalena Piorunek, której temat wystąpienia brzmiał: Młodzież wobec przyszłości edukacyjnozawodowej. Style $i$ strategie projektowania kariery na etapie adolescencji. Podkreślono $\mathrm{w}$ nim rolę adolescencji w kontekście planowania przyszłości, w tym kariery zawodowej. Ponadto, Pani Profesor wskazała i omówiła strategie projektowania kariery stosowane przez młodych dorosłych. Podsumowania drugiej sesji plenarnej konferencji dokonała dr Kamila Słupska, podkreślając, iż każda zmiana społeczna jest odczytywana jako szansa na poprawę warunków życia w różnych jego sferach, zarówno tych materialnych, jak i niematerialnych. Szybko jednak okazuje się, iż ta zapowiedź przemian interpretowanych w kategoriach ulepszania rzeczywistości ma też inny wymiar, pełen sprzeczności i paradoksów. Dlatego, tak istotna staje się analiza przestrzeni aktywności - między edukacją a rynkiem pracy.

Trzecią sesję plenarną, zatytułowaną: Świat społecznych wymagań, opatrzono hasłem: „Młodzież próbuje się do niego przystosować, odpowiada na stawiane jej wyzwania". Doktor hab. Waldemar Segiet otwierając tę sesję, zwrócił uwagę, że młode pokolenie musi wybrać z mnogości wzorców zachowań, chaosu wartości i niejednoznaczności norm coś istotnego, by z sukcesem usytuować się w społeczeństwie. W tej części sesji jako pierwsza wystąpiła prof. dr hab. Ewa Jarosz, która przygotowała referat: Obywatelstwo dzieci i młodzieży - retoryka wskazań i rzeczywistość. Pani Profesor podkreśliła w nim postrzeganie dzieci i młodzieży przez dorosłe społeczeństwo jako pełnoprawnych obywateli. Następnie, z wykładem zatytułowanym: Zdrowie psychospołeczne młodzieży czasu współczesnych przemian - konteksty kształtowania umiejętności życiowych wystąpiła prof. dr hab. Ewa Syrek. Zaprezentowała w nim, jak młodzież we współczesnym świecie, który charakteryzuje się silną dynamiką zmian, pojmuje zdrowie i związane $\mathrm{z}$ nim pojęcia oraz w jaki sposób przebiega współcześnie u młodych dorosłych proces kształtowania umiejętności życiowych. Kolejnym prelegentem był prof. dr hab. Tadeusz Pilch, który wygłosił, przygotowany we współpracy z prof. dr hab. Wioletą Danilewicz, referat zatytułowany: Młodość między wolnością a przymusem. Refleksje nad emigracją. Pan Profesor podją w nim próbę odpowiedzi na pytanie: dlaczego młodzi ludzie emigrują? Czy jest to wyraz wolności czy swoistego przymusu? Podsumowania trzeciej części sesji dokonał dr hab. Waldemar Segiet, podkreślając, że młodzież doświadcza rozproszenia znaczeń, relatywizacji, swobody, że wkracza w ten sposób na teren weryfikacji idei i ideologii, które powinny być już wcześniej zweryfikowane, czytelne i jasne. Pozostawił też uczestników konferencji ze skłaniającym do refleksji pytaniem: czy młodzież jako aktywny podmiot poradzi sobie z wyborami spośród rywalizujących o prymat konstrukcji społecznych? 
Ostatnia część sesji została zatytułowana: Portretowanie dobrych praktyk - własnych $i$ cudzych. Jej mottem przewodnim były słowa: „Młodzież rozpoznaje zaplecze kreatywności, potrzebuje też akceptacji otoczenia". Doktor Kamila Słupska wprowadziła słuchaczy m.in. w istotę spotkań interkulturowych, które stanowią przejaw kontaktu między różniącymi się kulturami, który może odbywać się w sposób pośredni, prawie bezpośredni lub bezpośredni. Tę część sesji rozpoczął Andre Berndt, który przygotował referat zatytułowany: Sozialpädagogische Arbeit mit jugendlichen Fussballfans (Praca socjalno-pedagogiczna z młodymi kibicami piłki nożnej). Wskazał w nim, jak działania z dziedziny pedagogiki społecznej i pracy socjalnej mogą być wykorzystywane $\mathrm{w}$ pracy z młodymi kibicami piłki nożnej. Ostatnim wystąpieniem na konferencji była prezentacja przygotowana przez Julię Kamenz. Nosiła ona tytuł: Interkulturelle Jugendbegegnungen als Form des informellen Lernens in der heutigen interkulturellen Gesellschaft (Interkulturowe spotkania młodzieży jako forma edukacji pozainstytucjonalnej w dobie współczesnego społeczeństwa interkulturowego). Prelegentka $\mathrm{w}$ prezentacji swej wskazała, jak istotnym elementem edukacji pozainstytucjonalnej są spotkania interkulturowe młodych ludzi w kontekście ich funkcjonowania. Doktor Kamila Słupska podsumowując ostatnią sesję plenarną konferencji podkreśliła, że wspomaganie młodzieży to nie tylko reakcja na sytuację trudną, w jakiej się ona znalazła i konkretna pomoc, ale również dawanie jej szansy odnalezienia własnych pasji, zainteresowań i wskazywanie obszarów mogących stanowić pola jej aktywności.

Moderatorzy - dr hab. Waldemar Segiet i dr Kamila Słupska - po zakończeniu wszystkich wystąpień prelegentów otworzyli obrady plenarne. Podczas ich trwania prof. dr hab. Barbara Smolińska-Theiss postawiła podsumowującą tezę, odnoszącą się do powyższych rozważań. Zwróciła uwagę, iż podstawą pedagogiki społecznej winno być przede wszystkim zajęcie stanowiska odnośnie problemów socjalnych młodzieży.

Oficjalnego zakończenia i podsumowania konferencji dokonała dr hab. Katarzyna Segiet - Przewodnicząca Komitetu Naukowego, która podziękowała wszystkim prelegentom oraz słuchaczom za przybycie i owocne obrady, które stanowiły inspirację do dalszych przemyśleń i poszerzyły obszar badań pedagogiki społecznej. Podkreśliła w zakończeniu, iż pomimo że człowiek funkcjonuje w świecie, w którym logika rynku ukazuje duży wpływ przedmiotów na osobowość jednostki, to nadal w procesie kształtowania się tożsamości młodzieży istotną rolę odgrywają inni ludzie, stanowiący ważne ogniwo w ich rozwoju. 